\title{
Do stigma and disclosure of HIV status are associated with adherence to antiretroviral therapy among men who have sex with men?
}

\author{
Lu'lu Nafisah', Pandu Riono ${ }^{2}$, Toha Muhaimin ${ }^{2}$ \\ ${ }^{1}$ Department of Public Health, Faculty of Health Sciences, Jenderal Soedirman University, Central Java, Indonesia \\ ${ }^{2}$ Department of Biostatistics and Population, Faculty of Public Health, West Java, Indonesia
}

\begin{abstract}
Introduction: People living with human immunodeficiency virus (HIV)/acquired immunodeficiency syndrome (AIDS) (PLWHA), especially men who have sex with man (MSM) suffer from double stigma because of their sexual behavior and HIV status; therefore, many of them do not reveal their status to others. Unfair treatment of health workers experienced by MSM negatively impacts their health, particularly their adherence to antiretroviral therapy. Non-compliance with therapy leads to poor conditions of PLWHA and increased transmission of HIV to their sexual partners. The aim of this study was to examine whether perceived stigma and disclosed HIV status are associated with antiretroviral therapy (ART) non-adherence among MSM.

Material and methods: A cross sectional study was conducted from April to July 2018 in two private clinics in DKI Jakarta, which are often visited by MSM. Thirty-eight adult MSM who had been on ART for $\geq 6$ months with a complete medical record were included in this study, using a purposive sampling method. Quantitative data were collected with a structured direct interview and recorded in STATA v.14 for analysis.

Results: The average age was 31 years (SD \pm 5.38 ), $94.74 \%$ of participants did not have a formal employment and were not married, and $65.79 \%$ completed undergraduate education. $50 \%$ felt a high stigma related to their HIV status; however, $63.16 \%$ revealed their status to others, especially health workers and $52.63 \%$ had a good relationship with doctors. There was no significant relationship between perceived stigma and disclosure of status with adherence to ART therapy.

Conclusions: Perceived stigma should be minimized by establishing a good patient-doctor relationship. Therefore, MSM would be willing to disclose their HIV status and sexuality, and hence help to achieve optimal adherence to antiretroviral therapy.
\end{abstract}

HIV AIDS Rev 2020; 19, 4: 244-251

DOI: https://doi.org/10.5114/hivar.2020.101594

Key words: perceived stigma, disclosure, adherence, ART, ARV, MSM.

\section{Introduction}

Men who have sex with men (MSM) and transgender women are subjected to high levels of human immunodeficiency virus (HIV)-related stigma and often criminalized,

Address for correspondence: Lu'lu Nafisah, Department of Public Health, Faculty of Health Sciences, Jenderal Soedirman University, Central Java, Indonesia, 53123, e-mail: luluhatta@gmail.com

affecting access to quality care for sexual health, HIV prevention, and treatment $[1,2]$. Also, MSM receive stigma, discrimination, judgment, and unfair treatment by health workers in several health services. This negative experience

Article history:

Received: 27.10 .2019

Received in revised form: 02.06 .2020

Accepted: 18.08.2020

Available online: 30.11 .2020
International Journal of HIV-Related Problems

HIV \& AIDS

R e vi e w 
prevents them from getting quality health services and influences their decision whether to continue the treatment [3-6].

The ratio of people living with HIV/acquired immunodeficiency syndrome (AIDS) (PLWHA) between men and women in Indonesia is $2: 1$, and the highest percentage of HIV risk factors are sexual risk behavior among heterosexuals (71.9\%), homosexuals (MSM) (21.3\%), perinatal (3.6\%), and using unsterile syringes (2.5\%) [7]. DKI Jakarta Province is one of the 5 provinces with the highest incidence of HIV and AIDS. One private clinic that provides antiretroviral therapy (ART) services in DKI Jakarta is Angsamerah Institution. The Angsamerah Institution strongly upholds the philosophy of openness, therefore many key population groups including MSM feel comfortable using Angsamerah health services. This comfort arises because they obtain services at an agreed time, therefore they do not wait long, do not meet with other service users, and do not interfere with their daily activities schedule. $75 \%$ of patients accessing HIV services are men, out of which, 50\% are MSM. Since the establishment of the Angsamerah clinic at the end of 2013, KYA has provided tests to around 300 MSM, out of which nearly $20 \%$ were HIV-positive and most of them continued their HIV treatment received from KYA [8].

Strict adherence to ART is required to prevent treatment failure, drug resistance, and reduce HIV transmission $[9,10]$. The results of previous studies in Indonesia showed that adherence to ART was still not optimal, below $80 \%$ [11-13]. Research on ART adherence in MSM group shows lower adherence at only $36.4 \%$ in Bali [14]. In Angsamerah in 2016, out of 114 PLWHA who had seen their viral load, 97 PLWHA (85\%) had undetectable viral load (VL), still below the target of $90 \%$ of undetectable VL in the blood.

Research has identified factors associated with ART adherence, such as gender, knowledge, education level, duration of $\mathrm{ART}$, depression, internal motivation, drug and alcohol use, family support, travel time to hospital, ART availability, health worker's attitude, and patient-doctor relationship [15-18]. The MSM group is often associated with several risk behaviors, including alcohol consumption, smoking, anal sex, temporary sex partners, and drug use. These risk behaviors affect MSM adherence to ARV therapy, while alcohol consumption increases the incidence of hepatotoxicity [17-26].

High levels of perceived HIV-related stigma, classified as barriers from adherence [19, 27-29], can prevent HIV disclosure and therefore stop HIV patients from accessing social support. MSM and transgender women who are open about or have disclosed their sexual behavior, appear to be the most affected by stigma [30]. Sexual stigma experienced by MSM also limits them to maintain stable partners, so they tend to have non-permanent partners. This causes others to not know their partner's HIV status and has a high potential to become infected with HIV [31,32]. Other effects of not disclosing sexual behavior include deteriorating mental health, reduced involvement in HIV services, and increase of other risky sexual behaviors [33, 34]. Lyons et al. suggested that although disclosure of sexual behavior among
MSM can lead to various humiliations, it can improve mental health status, HIV-related outcomes as well as awareness and acceptance of MSM group [30].

PLWHA's acceptance of HIV status influences the adherence to ARV therapy because it is closely related to the disclosure of HIV status to the family, depression, and internal motivation to live longer and healthier lives. PLWHA who receive their HIV status are encouraged to adhere to ARV therapy $[17,35,36]$. However, a study by Aye et al. revealed that patients who disclosed their HIV status to others were less likely to comply with ART than those who did not disclose their status [23]. Other studies indicated that although disclosure can lead to a support from a social network, there is a high level of perceived stigma with initial disclosure to a trusted family member rather than a partner [37]. These differences suggest that the association between adherence, social support, disclosure, and stigma is complicated and dynamic.

There is a need to better understand the role of stigma and disclosure of HIV status in driving the adherence among PLWHA in Indonesia. Especially considering the conditions in Indonesia, with high HIV-positive MSM ratios and percentages, where same-sex relationships are still a law offence and stigma and discrimination are the main obstacles in HIV prevention as well as treatment programs and services. The aim of this study was to contribute to the literature by analyzing how social support, perceived stigma, and disclosure of HIV status are associated with non-adherence among HIV-positive MSM, who started their ART at a private clinic.

\section{Material and methods}

\section{Study area}

This research was conducted between April and July 2018 at two private clinics in DKI Jakarta: the Angsamerah Foundation Clinic and the Angsamerah Clinic. Both clinics were chosen as research sites because the clinic manager had given research permission, and many key populations were accessing HIV treatment and care services in those clinics. In the study, $75 \%$ of patients were male, out of which $50 \%$ were MSM. Angsamerah is widely accessed by key groups, since it provides services based on an appointment system; it is operating from one place, so that confidentiality is guaranteed, with shorter waiting times and longer consultation times with health workers. Since the establishment of the Angsamerah Clinic at the end of 2013, Angsamerah has given tests to around 300 MSM, out of which nearly $20 \%$ were HIV-positive and most of them continued with HIV treatment received from Angsamerah [4].

\section{Study design and population}

This was a cross-sectional study, and included individuals living with HIV/AIDS currently undergoing ARV therapy at a study site until January $2018(n=380)$. The re- 
search sample was determined using purposive sampling, and the sample in this study was PLWHA at the study site who met the inclusion criteria $(n=38)$. Inclusion criteria consisted of PLWHA from the MSM group aged 18 years or older, length of antiretroviral therapy of 6 months or more, having a complete medical record, and PLWHA who were willing to participate in the study. The exclusion criteria were PLWHA who did not complete the questionnaire, PLWHA with severe psychiatric disorders, and those who were in an unconscious state.

\section{Data collection}

The source of the data used in this study came from medical records and primary data taken from the results of the research questionnaires completed by PLWHA. Data collection tools used included medical record data sheets and research questionnaire sheets. Medical record data sheet was used to collect written information on patient's medical record. Questionnaire sheets were used to collect data on individual characteristics, which were not found in the medical record. The present study focused on the perceived stigma of $38 \mathrm{MSM}$ and the disclosure of their status, and a relationship of these two factors, with MSM adherence to ARV therapy (Table 2). Other information collected included socio-demographic characteristics of the respondents, including age, sex, marital status, education level, length of formal education, occupation, and with whom the respondent lived (Table 1). A short version of Berger questionnaire was applied, which was previously used in a stigma and discrimination survey by the UI Health Research Center, with 22 statements. This instrument uses a four-point Likert scale, with "strongly disagree", "disagree", "agree", and "strongly agree". A patient-doctor relationship was assessed using the patient-doctor relationship questionnaire (PDR 1-9) from van der Feltz-Cornelis et al., 2004. This questionnaire consists of 9 statements, with a five-point Likert scale including "strongly disagree", "disagree", "agree", "strongly agree", and "strongly agree". The level of adherence using the pill count method refers to the definition of adherence from the Ministry of Health of 2007, which was previously applied in Ubra study in Papua, with data obtained from an overview of responds on HIV care and ARV therapy.

In the present study, the researchers collected data with the help of health workers in the study area who were experienced and willing to help. Before collecting data, researchers submitted a research permit and an ethical approval to the leader of study site. Then, the researcher explained the criteria for PLHIV who could be included in the study and the process of filling out the questionnaire to health workers at the study site. Next, the team distributed online questionnaire links and paper questionnaires to health workers at both study sites. Then, the participants completed the questionnaires after reading the informed consent provided by the team. After completing the questionnaires, the medical records of patients who participated in the study were examined, and the researchers analyzed the whole study data of participants.

\section{Data analysis and ethical considerations}

The missing information was immediately corrected on the same day, until 3 days later. The results of the study were analyzed using univariable analysis, which aimed at obtaining an overview of the distribution and frequency of data, with the help of STATA version 14. Descriptive data presented in the table included frequencies, averages, and standard deviations for numeric variables and proportions for categorical variables. $\chi^{2}$ test was carried out to identify whether stigma perceptions and disclosure status were related to adherence to antiretroviral therapy among MSM. This research has been reviewed and declared as ethical by the Ethics Commission for Research and Community Service, Faculty of Public Health, University of Indonesia, with letter number of 287/ UN2.F10/ PPM.00.02/ 2018. A research permit has also been obtained from clinical managers at both research sites.

\section{Results}

In total, $38 \mathrm{MSM}$ were included into the present study. The age varied from 24 years to 47 years, with an average age of 31 years. The majority of respondents did not have formal employment (94.74\%), were not married (94.74\%), had formal education for more than 12 years $(81.58 \%)$, and most of them completed undergraduate education (65.79\%). Most of the respondents lived alone (34.21\%) and lived with family (34.21\%). $65.79 \%$ of the participants did not suffer from opportunistic infections, but some of them reported ARV side effects (50.00\%). A part of respondents had been on ARV therapy for more than 2 years (50\%). PLWHA who have been on ART for more than 2 years were considered to pass the critical period of the first 2 years. At that time, many ODHA dropped out because they could not accept their HIV status, experienced side effects at the beginning of ARV therapy, and difficulty adjusting their ARV daily schedule.

The majority stated that they had a good relationship with doctors (52.63\%), but did not follow the peer support group $(86.84 \%)$ and did not have friends during treatment (55.26\%). A good relationship with health workers is assessed from the patient's answers regarding 9 items of statements, including assistance given by doctors during treatment, providing adequate consultation time, feeling trustworthy with information and treatment provided by doctors, doctors' ability to understand patients, doctors' willingness to always help the patients, agreement with the doctor about the characteristics of medical symptoms experienced by the patient, available opportunities to discuss with the doctor, satisfaction with the treatment given by the doctor, and the ease of contacting or seeing a doctor. Although all aspects of the patient-doctor relationship in this study presented a good relationship, there was 1 respondent $(2.63 \%)$ 
Table 1. Characteristics of participants $(n=38)$

\begin{tabular}{|c|c|c|c|}
\hline Parameter & $n$ & (\%) & \\
\hline \multicolumn{4}{|l|}{ Age } \\
\hline$\geq 35$ years & 10 & 26.32 & \multirow{2}{*}{$\begin{array}{c}\text { Mean }=31 ; S D=5.38 \\
M i n=24 ; \operatorname{Max}=47\end{array}$} \\
\hline$<35$ years & 28 & 73.68 & \\
\hline \multicolumn{4}{|l|}{ Current employment } \\
\hline Employed & 36 & 94.74 & \\
\hline Unemployed & 2 & 5.26 & \\
\hline \multicolumn{4}{|l|}{ Current marital status } \\
\hline Never married & 36 & 94.74 & \\
\hline Currently married & 2 & 5.26 & \\
\hline \multicolumn{4}{|c|}{ Years of formal education } \\
\hline$>12$ years & 31 & 81.58 & \multirow{2}{*}{$\begin{aligned} \text { Mean } & =15 ; \text { SD }=2.14 \\
\text { Min } & =9 ; \operatorname{Max}=20\end{aligned}$} \\
\hline$\leq 12$ years & 7 & 18.42 & \\
\hline \multicolumn{4}{|l|}{ Education } \\
\hline $\begin{array}{l}\text { Not completed } \\
\text { high school }\end{array}$ & 2 & 5.26 & \\
\hline High school & 5 & 13.16 & \\
\hline $\begin{array}{l}\text { Completed } \\
\text { diploma program }\end{array}$ & 3 & 7.89 & \\
\hline Graduate degree & 25 & 65.79 & \\
\hline Post-graduate & 3 & 7.89 & \\
\hline \multicolumn{4}{|l|}{ Live with } \\
\hline Alone & 13 & 34.21 & \\
\hline Partners & 5 & 13.16 & \\
\hline Family & 13 & 34.21 & \\
\hline Child & 2 & 5.26 & \\
\hline Friends & 2 & 5.26 & \\
\hline \multicolumn{4}{|l|}{ Opportunistic infection } \\
\hline No & 25 & 65.79 & \\
\hline Yes & 13 & 34.21 & \\
\hline \multicolumn{4}{|c|}{ Reported side effect from ART } \\
\hline No & 19 & 50.00 & \\
\hline Yes & 19 & 50.00 & \\
\hline \multicolumn{4}{|l|}{ ART duration } \\
\hline$\geq 2$ years & 19 & 50.00 & \\
\hline$<2$ years & 19 & 50.00 & \\
\hline \multicolumn{4}{|c|}{ Patient-doctor relationship } \\
\hline Good & 20 & 52.63 & \\
\hline Poor & 18 & 47.37 & \\
\hline \multicolumn{4}{|c|}{ Participation in peer support groups } \\
\hline Yes & 5 & 13.16 & \\
\hline No & 33 & 86.84 & \\
\hline \multicolumn{4}{|l|}{ Treatment buddy } \\
\hline Yes & 17 & 44.74 & $\begin{array}{c}21.05 \% \text { partner; } \\
\text { 15.79\% friends; } \\
5.26 \% \text { NGO; } \\
2.63 \% \text { family }\end{array}$ \\
\hline No & 21 & 55.26 & \\
\hline
\end{tabular}

Table 1. Cont.

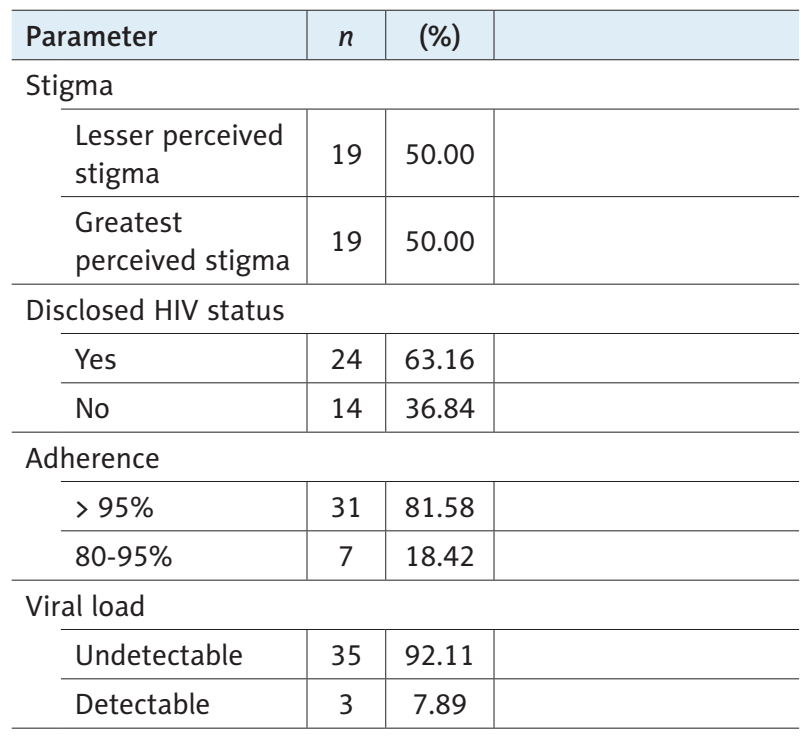

who stated "disagree" with the ease of contacting and seeing a doctor. This might be due to the process of making an appointment with a doctor through clinical telephone number/ clinical WA number/clinical email, and not directly contacting the doctor desired by the patient.

Some felt a high stigma related to their HIV status (50\%); however, $63.16 \%$ had revealed their status to others, especially health workers. This high stigma was revealed from many MSM who felt the need to be careful in revealing their HIV status (65.79\%), felt the need to hide their HIV/AIDS status (94.74\%), felt worried about the judgment of others (81.58\%), felt ashamed because of having HIV/AIDS (73.68\%), felt guilty $(65.79 \%)$, exiled $(65.69 \%)$, considered as disturbing the community (68.42\%), and disgusted by others (84.21\%).

The results of bivariate analysis showed no significant relationship between disclosure of status $(p=0.171)$ and perceived stigma with adherence to ARV therapy $(p=0.209)$.

\section{Discussion}

This study was the first assessment of perceived stigma and disclosure of HIV status among MSM in Indonesia. This study also described the prevalence of stigma and discrimination among MSM in Indonesia. We found no association between perceived stigma or disclosure of HIV status and adherence to ART among MSM in Indonesia. These results are in line with previous studies $[2,38]$.

Previous research observed that stigma is associated with adherence to ARV therapy $[13,18,19,39]$. Optimal adherence was reported in PLWHA with low stigma and discrimination [38-40]. Moreover, MSM face multiple humiliations, including HIV and homosexuality, and they may face discrimination from the public and health service providers, which prevents them from disclosing their status. Also, it prevents MSM from seeking HIV care and treatment, and 
Table 2. Analysis of the relationship between perceived stigma and disclosure of status, with the level of adherence in ARV therapy

\begin{tabular}{l|c|c|c|c}
\hline \multirow{2}{*}{ Characteristics } & \multicolumn{2}{|c|}{ Adherence } & \multirow{2}{*}{ Total } & \multicolumn{2}{c}{$p$-value } \\
\cline { 2 - 4 } & $>95 \%$ & $80-95 \%$ & 24 & 0.171 \\
\hline Disclosed to other & $18(75.00)$ & $1(7.14)$ & 14 & 19 \\
\hline Not disclosed & $13(92.86)$ & $2(10.53)$ & 19 & 0.209 \\
\hline Lesser perceived stigma & $17(89.47)$ & $5(26.32)$ & \\
\hline
\end{tabular}

obtaining social support $[34,38,41,42]$. However, stigma from healthcare providers in this study site was less than stigma in other health services. The prevalence of adherence to ARV therapy was also higher than compliance elsewhere. Possible reasons related to these differences include a better ratio between health workers and patients and longer consultation time for clients at a site of private sector, with relatively better resources than in the public sector [42]. One doctor at the study site was estimated to treat 5-6 patients each day, less than in other ART services. The ratio of doctors and patients was also related to the length of counseling time of each patient and subsequently related to the quality of service. The duration of counseling for each patient in the two research sites varied between 30-90 minutes.

Another reason for the results of this study to differ from other research was the characteristics of MSM group accessing ARV therapy services in these two private clinics. Most MSM at this study were well-educated and working professionals, which demanded good performance and productivity. Therefore, their internal motivation to stay healthy and fit increased their adherence to antiretroviral therapy. People with higher education and active work have access to medical services, communication skills, self-confidence, mental health, and better social support, which results in reduced perceived stigma [23, 43-46]. PLWHA who worked were $27 \%$ more likely to take ARVs than those who were unemployed. The positive effects of adherence to antiretroviral therapy were sensed by workers, namely retaining and increasing the ability to find and maintain work. HIV-infected workers who did not receive ART tend to be unable to work than those who had just started and were compliant with ARV therapy [45].

This study found that perceived stigma by MSM was still very high. The MSM community kept its status a secret from the community because their status is contrary to local culture and religion. Only 13\% of MSM attend peer support groups. They do not want to be involved in peer support groups as they are worried that their HIV status will be disclosed to many people. MSM infected with HIV are more willing to reveal their status as PLWHA to their families, but not their status as MSM. They will only be open with their fellow MSM, even with PLWHA companions they are still hesitant to reveal their homosexual status [42].

Although some respondents expressed perceived high stigma, most MSM (63.16\%) revealed their HIV status to health workers. Several studies indicated that disclosure of HIV status was a predictor that increases adherence to ART $[17,47,48]$. Disclosure of HIV status was the first stage to create a supportive relationships with sexual partners and families, and therefore facilitate the acceptance and continuation of ART [49]. Disclosure of HIV status helped reducing stress and isolation due to increased social support and compliance [50]. Family members and friends act as treatment partners and provide moral and material support. This also supports negotiations for safer sex, which have a positive impact on controlling the spread of HIV [47]. Other report showed the opposite, with an increased risk of non-compliance among individuals who revealed their HIV status to others [23].

In the present study, disclosure of same-sex practices to a healthcare provider was strongly associated with an increased level of education, and suggests that MSM with higher education level in Indonesia are potentially receiving more competent care. Research shows that higher levels of education have higher levels of HIV stigma, and lower education is a protective factor against perceived stigma [51]. However, other study observed that the higher the level of education, the less stigmatized PLWHA [43]. Possible explanations for this association are that individuals with higher levels of education usually have higher social status, better working conditions, more adequate social support, and live in urban areas, with easy access to health services. Thus, they may be significantly more affected by receiving a positive HIV diagnosis $[43,51]$.

Most MSM in this study had been on ARV therapy for more than 2 years and had a good relationships with doctors. The results of previous studies reveal that PLWHA who were already under HIV care were more likely to have a good partner relationships and greater social support, thereby increasing adherence to ARV therapy $[52,53]$. Even though some participants felt a high level of HIV-related stigma, with strong support from health workers and MSM education level, they were able to motivate themselves to remain compliant to ARV therapy. $81 \%$ reported compliant and $92 \%$ undetectable viral load, higher than other study in Indonesia. Previous studies indicated that risk factors were related to the level of adherence to therapy [18, 38, 41]. MSM tends to have higher adherence than other risk factors [54]. This may be due to an increase in social support networks for homosexual patients living with HIV and involvement in gay community, which allows better interaction and therefore 
encourages good adherence to ART. PLWHA who participated in peer support groups stated that they felt more comfortable, relaxed, and strong, and could increase their knowledge $[55,56]$. However, other research revealed that support from friends or NGOs and discussions about treatment with friends were not significantly related to adherence [20].

This finding showed that only $13 \%$ of MSM followed peer support groups, but the majority of MSM reported compliance and undetectable viral load. Although PLWHA do not participate in peer support groups, they receive adequate counseling and education from health workers, and therefore encourage their adherence to therapy. Higher education levels were reported to help PLWHA to receive and understand information provided by health workers during counseling process [44]. PLWHA in this study mostly took education up to the tertiary level. Patients without formal education failed to comply with ARV therapy due to poor patients' communication skills, stigma, and lack of trust and confidentiality to health workers. This illustrates the importance of health personnel counseling, routine visits, and communication, and is supported by the ability of PLHIV to receive and absorb information delivered by health workers $[53,57,58]$. Previous research reported an injustice between empowered and powerless MSM as well as between MSM and the general population. Therefore, efforts are needed, which specifically aim at MSM groups who are often stigmatized $[1,59,60]$. A comprehensive anti-stigma approach involving the community, health service providers, government, researchers, and many others is necessary to create a model of health services that is safe, trusted, and comfortable, and consequently, increase access and utilization of HIV services for MSM groups in Indonesia.

\section{Limitations}

There are several limitations in this study. This study used a cross-sectional design that estimated adherence at one point of time, while therapeutic adherence is a dynamic process. Casual relationships between ARV compliance and risk factors cannot be identified using this study design. The level of adherence was assessed using patient self-reports, which recall bias and or information bias might cause inaccurate reporting. To avoid information bias in this study, especially on the level of medication adherence, the remaining ARV reported by respondents was adjusted to the medical records at the study site, the latest CD4 count, and viral load. This research was conducted in two private clinics in one province in Indonesia, therefore the results cannot be generalized to other regions and also other health service facilities. Future studies are suggested using valid instruments to investigate a risk behaviors among MSM groups in Indonesia, such as drug and alcohol use, condom use, number of sex partners, and mental health. Despite limitations mentioned above, this was the first study on MSM conducted in a private clinic that provides ARV services in DKI Jakarta, using a multi-method approach to measure adherence, and provided a strong foundation for further research, especially regarding care, support, and treatment among MSM groups.

\section{Conclusions}

The results shows that the perceived stigma and disclosure of HIV status were not significantly related to the level of MSM adherence to antiretroviral therapy. This study suggests a clinical setting that ensures the confidentiality and comfort of MSM in antiretroviral therapy as well as a good relationship between patients and doctors. MSM trust in health workers can reduce the stigma experienced by MSM. Another finding is the importance of patient's ability to absorb information conveyed by doctors, which can be helpful in achieving undetectable viral load.

\section{Acknowledgment}

The authors thank all health workers at the Angsamerah Foundation Clinic and Angsamerah Clinic for granting research permission and assisting during the data collection process. The author also thanks the respondents who agreed to participate in the study. We also thank the Indonesian Endowment Fund for Education (Lembaga Pengelola Dana Pendidikan/ LPDP) for providing research funding assistance.

\section{Conflict of interest}

The authors declare no potential conflicts of interest with respect to the research, authorship, and/or publication of this article.

\section{References}

1. Beyrer C, Baral SD, van Griensven F, et al. Global epidemiology of HIV infection in men who have sex with men. Lancet 2012; 380: 367-377.

2. George S, McGrath N. Social support, disclosure and stigma and the association with non-adherence in the six months after antiretroviral therapy initiation among a cohort of HIV-positive adults in rural KwaZulu-Natal, South Africa. Aids Care 2019; 31: 875-884.

3. Stojisavljevic S, Djikanovic B, Matejic B. "The Devil has entered you": a qualitative study of men who have sex with men (MSM) and the stigma and discrimination they experience from healthcare professionals and the general community in Bosnia and Herzegovina. PLoS One 2017; 12: e0179101.

4. Ogunbajo A, Kershaw T, Kushwaha S, Boakye F, Wallace-Atiapah $\mathrm{N}$, Nelson LE. Barriers, motivators, and facilitators to engagement in HIV care among HIV-infected Ghanaian men who have sex with men (MSM). AIDS Behav 2018; 22: 829-839.

5. Fisher CB, Fried AL, Macapagal K, Mustanski B. Patient-provider communication barriers and facilitators to HIV and STI preventive services for adolescent MSM. AIDS Behav 2018; 22: 3417-3428.

6. Micheni M, Kombo BK, Secor A, et al. Health provider views on improving antiretroviral therapy adherence among men who have sex with men in coastal Kenya. AIDS Patient Care STDS 2017; 31 : 113-121.

7. Kemenkes RI. Laporan Situasi Perkembangan HIV-AIDS Di Indonesia. 2016. Available at: http://www.aidsindonesia.or.id/ck uploads/files/Laporan\%20HIV\%20AIDS\%202016\%20-\%20Triwulan\%203.pdf (Accessed: 27.02.2017). 
8. Kusumowardoyo ChL. Berkualitas, Non-diskriminatif, dan Terjangkau: Klinik Yayasan Angsamerah sebagai Model Kemitraan Publik dan Swasta dalam Menyediakan Layanan untuk LSL. 2018. Available at: http://www.kebijakanaidsindonesia.net/id/artikel/artikel-tematik/ 956-berkualitas-non-diskriminatif-dan-terjangkau-klinik-yayasan -angsamerah-sebagai-model-kemitraan-publik-dan-swasta-dalammenyediakan-layanan-untuk-lsl (Accessed: 15.02.2018).

9. Peltzer K. Social grants for people living with HIV and on antiretroviral therapy in KwaZulu-Natal, South Africa: a longitudinal study. SAHARA J 2012; 9: 6-14.

10. Sari NH, Rusdji SR, Anas R. Hubungan Tingkat Kepatuhan Konsumsi Obat Anti Retro Viral (ARV) Pada Pasien HIV dengan Kejadian Infeksi Protozoa Usus di RSUP Dr.M.Djamil Padang. Jurnal Kesehatan Andalas 2017; 6: 523-529.

11. Ubra RR. Faktor-faktor yang berhubungan dengan kepatuhan pengobatan minum ARV pada Pasien HIV di Kabupaten Mimika Provinsi Papua Tahun 2012. Thesis. (2012). FKM UI. Depok.

12. Anesta HC, Sriati A, Hidayati NO. Motivasi Minum Obat Antiretroviral (ARV) dan Perilaku Kepatuhan Klien HIV AIDS Dampingan LSM Rumah Cemara Di Bandung. Nursing Current Journal 2014; 2.

13. Safira N. Rahayu Lubis, dan Rasmaliah. Faktor-Faktor yang Berhubungan dengan Kepatuhan Penderita HIV AIDS Mengonsumsi Obat Antiretroviral (ARV) Di Klinik Voluntary Counseling and Testing (VCT) RSUP H.Adam Malik Medan Tahun 2014. Undergraduate thesis. (2015). FKM USU.

14. Wardani NNT, Sari KAK. 2018. Prediktor Kepatuhan Pengguna Antiretroviral Pada Orang Dengan HIV/AIDS Lelaki Seks Dengan Lelaki Di Klinik Bali Medika Tahun 2013 \& 2014. E-Jurnal Medika 2018; 7.

15. Ross AJ, Aung M, Campbell L, Ogunbanjo GA. Factors that positively influence adherence to antiretroviral therapy by HIV and/or AIDS patients and their caregivers. Afr J Prim Health Care Fam Med 2011; 3: 196.

16. Wakibi SN, Ng'ang'a ZW, Mbugua GG. Factors associated with non-adherence to highly active antiretroviral therapy in Nairobi, Kenya. AIDS Res Ther 2011; 8: 43.

17. Wasti SP, Simkhada P, Randall J, Freeman JV, van Teijlingen E. Factors influencing adherence to antiretroviral treatment in Nepal: a mixed methods study. PLoS One 2012; 7: e35547.

18. Hansana V, Sanchaisuriya P, Durham J, Sychareun V. Kongmany Chaleunvong, Suwanna Boonyaleepun, and Frank Peter Schelp. Adherence to Antiretroviral Therapy (ART) among People Living With HIV (PLHIV): a cross-sectional survey to measure in Lao PDR. BMC Public Health 2013; 13. http://www.biomedcentral.com/1471-2458/13/617

19. Heestermans T, Browne JL, Aitken SC, et al. Determinants of adherence to antiretroviral therapy among HIV-positive adults in subSaharan Africa: a systematic review. BMJ Global Health 2016; 1: e000125.

20. Gokarn A, Narkhede MG, Pardeshi GS, Doibale MK. Adherence to antiretroviral therapy. JAPI 2012; 60: 16-20.

21. Mukui IN, Ng'ang'a L, Williamson J, et al. Rates and predictors of non-adherence to antiretroviral therapy among HIV-positive individuals in Kenya: results from the Second Kenya AIDS Indicator Survey, 2012. PLoS One 2016; 11: e0167465.

22. Azar P, Wood E, Nguyen P, et al. Drug use patterns associated with risk of non-adherence to antiretroviral therapy among HIV-positive illicit drug users in a Canadian setting: a longitudinal analysis. BMC Infect Dis 2015; 15. DOI: 10.1186/s12879-015-0913-0.

23. Aye WL, Puckpinyo A, Peltzer K. Non-adherence to anti-retroviral therapy among HIV infected adults in Mon State of Myanmar. BMC Public Health 2017; 17. DOI: 10.1186/s12889-017-4309-5.

24. Cioe PA, Gamarel KE, Pantalone DW et al. Cigarette Smoking and Antiretroviral Therapy (ART) Adherence in a Sample of Heavy Drinking HIV-Infected Men Who Have Sex with Men (MSM). AIDS Behav 2017; 21: 1956.

25. Kalichman SC, Grebler T, Amaral CM, et al. Viral suppression and antiretroviral medication adherence among alcohol using HIV positive adults. Int J Behav Med 2014; 21: 811-820.
26. Koirala S, Deuba K, Nampaisan O, Marrone G, EkstroÈm AM, for the CAT-S group. Facilitators and barriers for retention in HIV care between testing and treatment in AsiaĐA study in Bangladesh, Indonesia, Lao, Nepal, Pakistan, Philippines and Vietnam. PLoS One 2017; 12: e0176914.

27. Bello SIBK. Quality of life of HIV/AIDS patients in a secondary health care facility, Ilorin, Nigeria. Baylor University Medical Center. Proceedings, (2013). Baylor University Medical Center, 116.

28. Treffry-Goatley A, Lessells R, Sykes P, et al. Understanding specific contexts of antiretroviral therapy adherence in rural South Africa: A thematic analysis of digital stories from a community with high HIV prevalence. PLoS One 2016; 11: e0148801.

29. Lyons C, Stahlman S, Holland C, et al. Stigma and outness about sexual behaviors among cisgender men who have sex with men and transgender women in Eswatini: a latent class analysis. BMC Infect Dis 2019; 19: 211.

30. Kennedy CE, Baral SD, Fielding-Miller R, et al. They are human beings, they are Swazi: intersecting stigmas and the positive health, dignity and prevention needs of HIV-positive men who have sex with men in Swaziland. J Int AIDS Soc 2013; 16 Suppl 3: 18749.

31. Stahlman S, Bechtold K, Sweitzer S, et al. Sexual identity stigma and social support among men who have sex with men in Lesotho: a qualitative analysis. Reprod Health Matters 2015; 23: 127-135.

32. Pitpitan EV, Smith LR, Goodman-Meza D, et al. "Outness" as a moderator of the association between Syndemic conditions and HIV risk-taking behavior among men who have sex with men in Tijuana, Mexico. AIDS Behav 2016; 20: 431-438.

33. Metheny N, Stephenson R. Disclosure of sexual orientation and uptake of HIV testing and hepatitis vaccination for rural men who have sex with men. Ann Fam Med 2016; 14: 155-158.

34. Hunter-Adams J, Zerbe A, Philips T, et al. The dimensionality of disclosure of HIV status amongst post-partum women in Cape Town, South Africa. Afr J AIDS Res 2017. DOI: 10.2989/16085906. 2017.1311932.

35. Croome N, Ahluwalia M, Hughes LD, Abas M. Patient-reported barriers and facilitators to antiretroviral adherence in sub-Saharan Africa. AIDS (London, England) 2017; 31: 995-1007.

36. Maman S, van Rooyen H, Groves AK. HIV status disclosure to families for social support in South Africa (NIMH project accept/ HPTN 043). AIDS Care 2014; 26: 226-232.

37. Mao Y, Li X, Qiao S, Zhou Y, Zhao Q. Ethnicity, Stigma and Adherence to Antiretroviral Therapy (ART) among People Living with HIV/AIDS in Guangxi, China. J AIDS Clin Res 2017; 8: 652.

38. Graham SM, Mugo P, Gichuru E, et al. Adherence to antiretroviral therapy and clinical outcomes among young adults reporting highrisk sexual behavior, including men who have sex with men, in coastal Kenya. AIDS Behav 2013; 17: 1255-1265.

39. Omosanya OE, Elegbede OT, Agboola SM, Isinkaye AO, Omopariola OA. Effects of Stigmatization/Discrimination on Antiretroviral Therapy Adherence among HIV-Infected Patients in a Rural Tertiary Medical Center in Nigeria. Journal of the International Association of Providers of AIDS Care 2014; 13: 260-263.

40. Liu Y, Osborn CY, Qian HZ, et al. Barriers and Facilitators of Linkage to and Engagement in HIV Care Among HIV-Positive Men Who Have Sex with Men in China: A Qualitative Study. AIDS Patient Care STDS 2016; 30. DOI: 10.1089/apc.2015.0296.

41. Lasti MH. Antiretroviral Drug Compliance Analysis (ARV) In Community LSL (Men Sex With Men) PLHIV In Parepare Town Of South Sulawesi. Thesis. Postgraduate Program. Universitas Hasanuddin. Makassar. 2017.

42. Thida A, Tun ST, Zaw SK, et al. Retention and risk factors for attrition in a large public health ART program in Myanmar: a retrospective cohort analysis. PLoS One 2014; 9: e108615.

43. Sekoni AO, Obidike OR, Balogun MR. Stigma, medication adherence and coping mechanism among people living with HIV atten- 
ding General Hospital, Lagos Island Nigeria. Afr J Prm Health Care Fam Med 2012; 4.

44. Okoronkwo I, Okeke U, Chinweuba A, Iheanacho P. Nonadherence Factors and Sociodemographic Characteristics of HIV-Infected Adults Receiving Antiretroviral Therapy in Nnamdi Azikiwe University Teaching Hospital, Nnewi, Nigeria. Hindawi Publishing Corporation. ISRN AIDS 2013. http://dx.doi.org/10.1155/2013/843794.

45. Nachega JB, Uthman OA, Peltzer K, et al. Association between antiretroviral therapy adherence and employment status: systematic review and meta-analysis. Bull World Health Organ 2015; 93: 29-41.

46. Nikus Fido N, Aman M, Brihnu Z. HIV stigma and associated factors among antiretroviral treatment clients in Jimma town, Southwest Ethiopia. Research and Palliative Care 2016; 8: 183-193.

47. Pennap GR, Abdullahi U, Bako IA. Adherence to highly active antiretroviral therapy and its challenges in people living with human immunodeficiency virus (HIV) infection in Keffi, Nigeria. J AIDS HIV Res 2013; 5: 52-58.

48. Li L, Lee SJ, Wen Y, Lin C, Wan D, Jiraphongsa C. Antiretroviral therapy adherence among patients living with HIV/AIDS in Thailand. Nurs Health Sci 2010; 12: 212-220.

49. Reda AA, Biadgilign S. Determinants of Adherence to Antiretroviral Therapy among HIV-Infected Patients in Africa. AIDS Res Treat 2012; 2012: 574656.

50. Palva V, Segurado AC, Filipe EMV. Self-disclosure of HIV diagnosis to sexual partners by heterosexual and bisexual men: a challenge for HIV/AIDS care and prevention. Cad Saude Publica 2011; 29: 1699-1710.

51. Li Z, Sheng Y. Investigation of perceived stigma among people living with human immunodeficiency virus/ acquired immune deficiency syndrome in Henan Province, China. Int J Nurs Sci 2014; 1: 385-388.

52. Conroy A, Leddy A, Johnson M, Ngubane $T$, van Rooyen $H$, Darbes L. 'I told her this is your life': Relationship dynamics, partner support and adherence to antiretroviral therapy among South African couples. Culture Health Sexuality 2017. DOI: 10.1080/13691058.2017.1309460.

53. Kiwuwa-Muyingo S, Walker AS, Oja H, et al. The impact of first year adherence to antiretroviral therapy on long-term clinical and immunological outcomes in the DART trial in Uganda and Zimbabwe. Trop Med Int Health 2012; 17: 584-594.

54. Jiamsakul A, Kumarasamy N, Ditangco R, et al. Factors associated with suboptimal adherence to antiretroviral therapy in Asia. J Int AIDS Soc 2014; 17: 18911.

55. Berry MC, Go VF, Quan VM, et al. Social environment and HIV risk among MSM in Hanoi and Thai Nguyen. AIDS Care 2013; 25: 38-42.

56. Ayala G, Makofane K, Santos GM, et al. (2014). HIV Treatment Cascades that Leak: Correlates of Drop-off from the HIV Care Continuum among Men who have Sex with Men Worldwide. J AIDS Clin Res 2014; 5: 331.

57. Demessie R, Mekonnen A, Amogne W, Shibeshi W. Knowledge and adherence to antiretroviral therapy among adult people living with HIV/AIDS at Tikur Anbessa specialized hospital, Ethiopia. Int J Basic Clin Pharmaco 2014; 3: 320-330.

58. Loeliger KB, Niccolai LM, Mtungwa LN, Moll A, Shenoi SV. Antiretroviral therapy initiation and adherence in rural South Africa: Community health workers' perspectives on barriers and facilitators. AIDS Care 2016. DOI: 10.1080/09540121.2016.1164292.

59. Minichiello SN, Casey K, Khienvichit J, et al. Increasing uptake of HIV counseling and testing (HCT) among men who have sex with men in Bangkok through service quality improvement. $18^{\text {th }}$ International AIDS Conference. International AIDS Society; 2010 July 18_23; Vienna, Austria. Abstract MOPE0831.

60. Scheibe A, Duby Z, Brown B, Sanders E, Bekker LG. Evaluation of a health care worker training program around sensitization around men who have sex with men (MSM) in Cape Town, South Africa. 6th IAS Conference on HIV Pathogenesis and Treatment. Int AIDS Soc 2011 July 17_20; Rome, Italy. Abstract CDD132. 